\title{
ANALISIS KINERJA KEUANGAN PADA PT. PERUSAHAAN LISTRIK NEGARA (PERSERO) PERIODE 2015-2017
}

\author{
Khairudin \\ Maya Dwi Anggraini \\ Universitas Bandar Lampung \\ Jl. ZA. Pagar Alam No.26, Labuhan Ratu, Bandar Lampung, 35142. \\ Telp.0721-701979, Fax 0721-701463
}

\begin{abstract}
ABSTRAK
Tujuan penelitian adalah untuk menganalisis kondisi keuangan dan kinerja keuangan PT. Perusahaan Listrik Negara (Persero) yang diukur menggunakan Rasio Likuiditas, Rasio Solvabilitas, Rasio Profitabilitas, Rasio Aktivitas dan Rasio Pasar. Jenis penelitian ini adalah penelitian kuantitatif, Sampel diambil dari Laporan tahunan perusahaan diperoleh melalui situs resmi PT Perusahaan Listrik Negara (Persero) periode 2015-2017. Analisis yang digunakan adalah analisis rasio dan uji beda rara-rata. Berdasarkan kajian teoritik dan hasil analisis data, maka dapat disimpulkan bahwa pada periode tahun 2015-2017 PT PLN (Persero) Pusat memiliki kinerja yang sangat baik dilihat dari segi rasio aktivitasnya berdasarkan nilai rasio perputaran persediaan (PP).
\end{abstract}

Kata Kunci: Analisis, Kinerja, Keuangan

\section{ABSTRACT}

The research objective is to analyze the financial condition and financial performance of PT. The State Electricity Company (Persero) measured using Liquidity Ratios, Solvability Ratios, Profitability Ratios, Activity Ratios and Market Ratios. This type of research is quantitative research. Samples taken from the company's annual report are obtained through the official website of the PT Perusahaan Listrik Negara (Persero) period 2015-2017. The analysis used is ratio analysis and average difference test. Based on theoretical studies and the results of data analysis, it can be concluded that in the 2015-2017 period PT PLN (Persero) Pusat has a very good performance in terms of its activity ratio based on the value of the inventory turnover ratio (PP).

\section{Keywords: Analysis, Performance, Finance}




\section{A. PENDAhuluan}

Perkembangan teknologi yang terus meningkat dengan pesat menyebabkan semakin diperlukannya keahlian dalam menganalisis laporan keuangan. Untuk itu manajer dituntut memilih informasi dalam jaringan yang luas untuk mengetahui kondisi perusahaan saat ini maupun perkiraan kondisi di masa yang akan datang. Dengan penganalisaan laporan keuangan akan membantu pihak-pihak yang berkepentingan dalam memilih dan mengevaluasi informasi dan hanya berfokus dengan informasi tersebut, sehingga setiap perusahaan dituntut untuk dapat meningkatkan daya saingnya masing-masing. Namun pada hakikatnya, hampir semua perusahaan mengalami masalah yang sama yaitu cara mengalokasikan sumberdaya yang dimiliki secara efektif dan efisien guna mencapai tujuan perusahaan yaitu memperoleh laba maksimal untuk mempertahankan eksistensi perusahaan.

Laporan keuangan merupakan sumber informasi sehubungan dengan posisi keuangan dan kinerja keuangan perusahaan. Data keuangan tersebut dianalisis lebih lanjut sehingga akan diperoleh informasi yang dapat mendukung keputusan yang dibuat. Laporan keuangan ini harus menggambarkan semua data keuangan yang relevan dan telah ditetapkan prosedurnya sehingga laporan keuangan dapat diperbandingkan agar tingkat akurasi analisis dapat dipertanggungjawabkan.

Analisis dan interprestasi keuangan mengkatagorikan beberapa teknik dan alat analisis yang dapat dipergunakan untuk menghasilkan informasi yang berguna bagi pihak intern dan ekstern yang terkait dengan perusahaan. Bagi manajemen, informasi yang diperoleh itu berfungsi sebagai salah satu bahan pertimbangan dasar dalam proses pengambilan keputusan pengkoordinasian dan pengendalian perusahaan. Pada Efektivitas dan efisiensi suatu perusahaan dalam menjalankan operasinya ditentukan oleh kemampuan perusahaan dalam memperoleh profitabilitas dan aktivitas dalam perusahaan. Dengan demikian penggunaan analisis rasio keuangan dapat menggambarkan kinerja keuangan yang telah dicapai. Untuk mendukung kelangsungan dan peningkatan usaha maka perusahaan perlu menganalisis laporan keuangan agar dapat diperoleh informasi tentang posisi keuangan perusahaan yang bersangkutan.

Informasi yang tersaji harus dianalisis dan diinterprestasikan lebih jauh lagi agar mempunyai nilai guna bagi manajemen perusahaan. Untuk manajemen, dalam melakukan analisis terhadap kinerja keuangan yaitu berupa analisis yang bersifat fundamental dan intergratif yang nantinya akan memberikan gambaran yang mendasar dan menyeluruh tentang posisi dan prestasi keuangan.

Ada beberapa cara untuk menilai kondisi kesehatan perusahaan dengan menggunakan analisis kinerja keuangan, namun dalam hal ini penulis hanya menggunakan analisis rasio aktivitas dan rasio profitabilitas serta analisis regresi linier berganda. Penulis menganggap hasil dari kedua rasio tersebut penting bagi perusahaan, karena menyangkut kelangsungan hidup perusahaan. Penilaian prestasi perusahaan bagi pihak manajemen, khususnya untuk mengukur profitabilitas perusahaan merupakan salah satu faktor penting untuk mengetahui tingkat efisiensi perusahaan. Tingginya profitabilitas perusahaan lebih penting dibanding laba maksimal yang dicapai perusahaan 
pada setiap periode akuntansi, karena dengan profitabilitas sebagai alat ukur, kita dapat mengetahui sampai sejauh mana kemampuan perusahaan untuk menghasilkan laba yang maksimal dibandingkan dengan modal yang digunakan oleh perusahaan. Untuk itu setiap pemimpin perusahaan dituntut agar mampu mengelola manajemen perusahaan dengan baik agar dapat mencapai tingkat efisiensi yang optimal dari penggunaan modalnya.

Seperti halnya dalam pengelolaan perputaran aktiva, di mana perputaran aktiva ini sangat penting untuk mengukur kemampuan perusahaan dalam mengelola manajemen khusus dalam bidang keuangan, Sebab pengelolaan aktiva sangat penting dalam peningkatan perolehan pendapatan perusahaan melalui penjualannya. Setiap komponen aktiva atau modal kerja khusus mampu memberikan kontribusi maksimal untuk menghasilkan tingkat pendapatan yang ingin dicapai oleh perusahaan.

Manajemen mempunyai kepentingan ganda dalam analisis kerja keuangan yaitu menilai perputaran aktiva dan profitabilitas operasi, serta menimbang seberapa efektif penggunaan sumber daya perusahaan. Penilaian atas efisiensi operasi sebagian besar dilakukan berdasarkan analisa atas laporan laba rugi, sedangkan efektivitas penggunaan sumber daya biasanya diukur dengan mengkaji ulang baik neraca maupun laporan laba rugi.

Untuk memastikan maka secara periodik dilakukan pengukuran kinerja perusahaan, bahwa tujuan perusahaan dapat tercapai dan mengetahui sejauh mana efektifitas operasi perusahaan dalam mencapai tujuan

Dilihat dari segi aktivitasnya, pada tahun 2013 perputaran persediaan perusahaan yakni 4,02. Pada tahun yang sama perputaran piutangnya sebesar 30,62 dan tato adalah 0,26 kali. Pada tahun 2014 perputaran persediaannya mengalami peningkatan sebesar 0,16 poin menjadi 4,18 kali. artinya perputaran persediaan perusahaan mengalami peningkatan yang baik. Dari segi perputaran piutang, perusahaan juga mengalami peningkatan dibandingkan pada tahun sebelumnya yakni dari 30,62 menjadi 31,70. Artinya terjadi peningkatan sebesar 1,08 poin. Begitupula tato yang meningkat dari 0,26 kali menjadi 0,29kali. Pada tahun 2015 perputaran persediaan terus mengalami peningkatan ke posisi 4,78, meningkat 0,60 poin dari tahun sebelumnya, begitupula dengan perputaran piutangnya yang meningkat tajam sebesar 2,50 poin ke posisi 34,20. untuk tato mengalami kenaikan dari 0,29 menjadi 0,35 kali. Sedangkan pada tahun 2016 baik perputaran persediaan maupun perputaran piutang mengalami penurunan masing-masing 4,29 dan 33,40 kali. akan tetapi tato mengalami pergeseran positif dari 0,35 ke 0,42 kali. Berdasarkan informasi tersebut dapat dikatakan bahwa kinerja perusahaan baik dari segi perputaran total aktiva dan sangat baik apabila dilihat dari segi perputaran piutangnya, apabila kita melihat dari segi aktivitasnya. Hal ini disebabkan karena pada periode tersebut meskipun mengalami fluktuasi, namun angka tersebut masih berada di atas standar rata-rata industri di Indonesia. Seperti halnya perputaran piutangnya yang menurut standar rata-rata industri dikatakan bahwa apabila perputaran piutang perusahaan berada pada dan atau sama dengan 4,87 kali per tahun perusahaan. Dari data pada tabel 1.3, dilihat bahwa perputaran piutang perusahaan pada periode tersebut selalu berada di atas angka 30 lebih. 
Sedangkan untuk perputran total aktiva berada di bawah standar yakni 2 kali, sedangkan pada periode tersebut selalu berada di bawah 1 kali.

Kinerja PT PLN (Persero) dilihat dari segi profitabilitasnya, tahun 2003 profit marginnya minus $3,13 \%$. Nilai return on investment dan return on equity-nya juga minus masing-masing 0,79\% dan 1,04\%. Pada tahun 2014 margin laba perusahaan mengalami peningkatan yang sangat drastic dari minus menjadi positif dengan angka yang juga besar dari minus 3,13\% menjadi positif $4,40 \%$. Sedangkan untuk rasio ROI dan ROE-nya masih mengalami sentiemen negatif dengan perubahan yang lebih buruk lagi yakni; untuk ROI dari minus $0,74 \%$ menjadi minus $0,95 \%$. Begitupula dengan nilai ROE dari minus $1,04 \%$ menjadi minus $1,42 \%$. Pada tahun 2015, margin labanya mengalami penurunan 3,58 poin ke posisi $0,82 \%$ sedangkan tahun berikutnya justru bernilai negatif menjadi minus $0,71 \%$. Untuk nilai ROI-nya justru mengalami penurunan tajam dari tahun 2004 yakni minus $2,23 \%$ dan tahun 2016 mengalami peningkatan posisif yakni $0,78 \%$. Sedangkan untuk ROE-nya, tahun 2015 mengalami penurunan tajam menjadi minus $3,52 \%$ dan sedikit mengalami perbaikan pada tahun berikutnya yakni minus 2,9\%. Berdasarkan informasi pada periode 2013-2016, disimpulkan bahwa kinerja perusahaan berdasarkan rasio profitabilitasnya dalam hal ini margin laba, ROI dan ROE-nya sangat buruk. Standar rasio profitabilitas industri untuk menyatakan bahwa kinerja suatu perusahaan baik apabila margin labanya sebesar $8,3 \%$, return on investment-nya sebesar $9,8 \%$, dan ROE-nya sebesar $12 \%$.

Kinerja keuangan suatu perusahaan akan memberikan kontribusi kepada pemilik perusahaan tersebut. Begitupula PT PLN (Persero) yang merupakan perusahaan monopoli bidang kelistrikan yang dimiliki oleh pemerintah. Kinerja keuangan perusahaan yang buruk akan memberikan kontribusi yang kecil kepada pemiliki dan bisa saja akan membebani pemilik. PT PLN (Persero) yang merupakan BUMN dimana PLN akan berkontribusi langsung kepada pendapatan Negara di sektor nonpajak. Jadi buruk tidaknya kinerja PLN, akan berdampak pada pendapatan negara, yang secara jelas berpengaruh terhadap pertumbuhan perekonomian Indonesia.

\section{B. METODE PENELITIAN}

Jenis penelitian ini adalah penelitian kuantitatif, Sampel diambil dari Laporan tahunan perusahaan diperoleh melalui situs resmi PT Perusahaan Listrik Negara (Persero) periode 2015-2017. Analisis yang digunakan adalah analisis rasio dan uji beda rara-rata.

\section{HASIL PENELITIAN DAN PEMBAHASAN}

Berdasarkan hasil penelitian untuk penilaian kinerja dengan menggunakan analisis rasio keuangan yaitu analisis rasio likuiditas, rasio solvabilitas, rasio profitabilitas, rasio aktivitas, dan rasio pasar pada perusahaan PT Perusahaan Listrik Negara (PLN) yaitu kinerja perusahaan PT Perusahaan Listrik Negara (PLN). berdasarkan hasil perhitungan analisis Rasio Likuiditas pada tahun 2015-2017 dengan penggunaan Rasio lancar dapat dinyatakan kurang baik karna rasio lancar mengalami fluktuasi cenderung menurun hal ini disebabkan menurunnya jumlah aktiva lancar dari tahun ke tahun yang diikuti kenaikan utang lancar perusahaan sehingga berpengaruh terhadap laba komprehensif dan juga menggunakan 
cash ratio dapat dinyatakan kurang baik dalam kinerja keuangannya karena perusahaan masih kurang mampu memanfaatkan penerimaan kas dan pengendalian pengeluaran kas yang tersedia.

Kinerja perusahaan PT Perusahaan Listrik Negara (PLN). berdasarkan analisis rasio solvabilitas sedikit mengalami kesulitan di dalam memenuhi semua kewajibankewajibannya karena perusahaan masih ada ketidak mampuan dalam menutup total hutang dengan total aset yang dimiliki dan masih tingginya ketergantungan permodalan perusahaan terhadap pihak luar. Kinerja perusahaan PT Perusahaan Listrik Negara (PLN). berdasarkan analisis rasio profitabilitas sudah baik. Pencapaian rasio-rasio yang relatif stabil, antara lain rata rata return on assets $8,4 \%$ dan return on equity sebesar 9,7\%. Kinerja perusahaan PT Perusahaan Listrik Negara (PLN). berdasarkan analisis rasio aktivitas sudah baik karena perusahaan efektif dalam memanfaatkan sumber daya yang ada baik itu modal kerja maupun asset tetap dalam menghasilkan pendapatan secara optimal.

Kinerja perusahaan PT Perusahaan Listrik Negara (PLN). berdasarkan analisis rasio pasar juga sudah baik. Pencapaian rasio-rasio yang relatif stabil, antara lain rata-rata rasio harga laba sebesar 5,32 kali dan rasio pembayaran dividen sebesar 9,11\%. Perusahaan baik dalam pembagian pendapatan yang dibayarkan sebagai dividen kepada investor dan bagian lain yang tidak dibagikan akan diinvestasikan kembali ke perusahaan.

\section{KESIMPULAN DAN SARAN 1. Kesimpulan}

Berdasarkan hasil penelitian untuk penilaian kinerja dengan menggunakan analisis rasio keuangan yaitu analisis rasio likuiditas, rasio solvabilitas, rasio profitabilitas, rasio aktivitas, dan rasio pasar pada perusahaan PT Perusahaan Listrik Negara (PLN). maka kesimpulan dalam penelitian ini adalah:

1) Kinerja perusahaan PT Perusahaan Listrik Negara (PLN). berdasarkan hasil perhitungan analisis Rasio Likuiditas pada tahun 2015-2017 dengan penggunaan Rasio lancar dapat dinyatakan kurang baik karna rasio lancar mengalami fluktuasi cenderung menurun hal ini disebabkan menurunnya jumlah aktiva lancar dari tahun ke tahun yang diikuti kenaikan utang lancar perusahaan sehingga berpengaruh terhadap laba komprehensif dan juga menggunakan cash ratio dapat dinyatakan kurang baik dalam kinerja keuangannya karena perusahaan masih kurang mampu memanfaatkan penerimaan kas dan pengendalian pengeluaran kas yang tersedia.

2) Kinerja perusahaan PT Perusahaan Listrik Negara (PLN). berdasarkan analisis rasio solvabilitas sedikit mengalami kesulitan di dalam memenuhi semua kewajibankewajibannya karena perusahaan masih ada ketidak mampuan dalam menutup total hutang dengan total aset yang dimiliki dan masih tingginya ketergantungan permodalan perusahaan terhadap pihak luar.

3) Kinerja perusahaan PT Perusahaan Listrik Negara (PLN). berdasarkan analisis rasio profitabilitas sudah baik. Pencapaian rasio-rasio yang relatif stabil, antara lain rata rata return on assets $8,4 \%$ dan return on equity sebesar 9,7\%.

4) Kinerja perusahaan PT Perusahaan Listrik Negara (PLN). berdasarkan 
analisis rasio aktivitas sudah baik karena perusahaan efektif dalam memanfaatkan sumber daya yang ada baik itu modal kerja maupun asset tetap dalam menghasilkan pendapatan secara optimal.

5) Kinerja perusahaan PT Perusahaan Listrik Negara (PLN). berdasarkan analisis rasio pasar juga sudah baik. Pencapaian rasio-rasio yang relatif stabil, antara lain rata-rata rasio harga laba sebesar 5,32 kali dan rasio pembayaran dividen sebesar 9,11\%. Perusahaan baik dalam pembagian pendapatan yang dibayarkan sebagai dividen kepada investor dan bagian lain yang tidak dibagikan akan diinvestasikan kembali ke perusahaan.

\section{Saran}

Berdasarkan hasil penelitian yang telah dilakukan, sebagai masukan dan upaya peningkatan kinerja keuangan PT Perusahaan Listrik Negara (PLN). dapat disarankan sebagai berikut:

1) Bagi pihak manajemen sebaiknya melakukan evaluasi dan meningkatkan kemampuan perusahaan dalam membayar kewajiban atau utang yang segera jatuh tempo pada saat ditagih dan sebaiknya perusahaan harus mampu membayar jangka pendek dengan aktiva lancar tanpa memperhitungkan sediaan atau piutang.

2) Perusahaan perlu untuk mempertimbangkan jumlah hutang yang akan digunakan sebagai sumber pendanaan. Hutang dalam jumlah besar akan dapat memberikan kesempatan bagi perusahaan untuk memperoleh keuntungan yang lebih besar namun dengan syarat bahwa perusahaan tersebut memiliki ekonomi yang baik.
3) Perusahaan perlu memperhatikan perkembangan rasio profitabilitas dan rasio aktivitas, apabila aktivitas suatu perusahaan terus meningkat sedangkan profitabilitasnya menurun atau stagnan, hal ini mengindikasikan bahwa perusahaan dalam menggunakan total aktivanya menciptakan pendapatan yang sudah baik namun dalam menghasilkan keuntungan masih kurang karena adanya kewajibankewajiban yang harus dipenuhi setiap tahunnya.

4) Perusahaan harus mampu meningkatkan volume pendapatan dengan skala besar dengan tujuan untuk meningkatkan jumlah pendapatan yang akan berimbas pada peningkatan laba perusahaan, serta melakukan ekspansi ke kotakota besar lainnya di Indonesia.

\section{DAFTAR PUSTAKA}

Agnes, Sawir. 2009. Analisis Kinerja Keuanan dan Perencanaan Keuangan Perusahaan. Jakarta: PT. Gramedia Pustaka Utama.

Arikunto, Suharsini. 2006. Prosedur Penelitian Suatu Pendekatan Praktek. Jakarta: PT Rineka Cipta.

Baridwan, Zaki. 2000. Intermediate Accounting, Edisi Ketujuh. Yogyakarta: BPFE.

Daft, Richard L. 2003. Manajemen Sumber Daya Manusia. Jakarta: Erlanga.

Darsono. 2009. Analisis Laporan Keuangan. Yogyakarta:Liberty.

Dibyo, Soemantri Priambodo. 2004. Refleksi BUMN 1993-2003. Yogyakarta: Media Pressindo.

Handoko, T. Hani. 2009. Manajemen, cetakan dua puluh. Yogyakarta: BPFE. 
Harahap, Sofyan Syafri. 2010. Analisis

Kritis Atas laporan Keuangan,

PT Rajagrafindo Persada, Jakarta.

Harahap, Sofyan Syafri. 2009.

"Analisis Kritis Atas Laporan

Keuangan". Jakarta:

RajaGrafindo Persada

Husein Umar. 2005. Metode Penelitian. Jakarta: Salemba Empat.

Jumingan. 2009. Analisis Laporan Keuangan. Jakarta: Bumi Aksara.

Keown, Arthur J. Et al. 2005. Financial management,

Principles and Aplications 10th Edition. New Jersey: Pearson Prentice Hall.

Margono. 2010. Metode Penelitian Pendidikan. Jakarta: Rineka Cipta.

Moekjiat. 2000. Kamus Manajemen. Bandung: CV. Maju Mundur.

Moh. Wahyudin Zarkasyi. 2008. Good Corporate Governance. Bandung: Alfabeta.

Munawir. 2007. Analisis Laporan Keuangan, Edisi Keempat.
Yogyakarta: Liberty.

Riyanto, Bambang. 2001. Dasardasar Pembelajaran Perusahaan. edisi keempa. Yogyakarta: BPFE.

Sartono, Agus. 2001. Manajemen Keuangan Teori dan Aplikasi. Yogyakarta:

BPEFYOGYAKARTA

Sucipto. 2003. Penilaian Kinerja Keuangan. Jurnal Akuntasi. Medan: Universitas Sumatra Utara.

Sukmadinata, Nana Syaodih. 2013. Metode Penelitian Pendidikan. Bandung: PT. Remaja Rosdakarya.

Sutrisno. 2009. Manajemen Keuangan: Teori, Konsep, dan Aplikasi. Yogyakarta: Ekononisia.

Wahyono. 2002. Orientasi Pasar dan Inovasi, Pengahruh terhadap Kinerja. Indonesia: Jurnal Sains Sawir, Agnes, 2009. Analisa Kinerja Keuangan dan Perencanaan keauangan Perusahaan, PT. Gramedia Pustaka Utama, Jakarta. 